\title{
METHODOLOGY OF SAFETY AND QUALITY OF LIFE ON THE BASIS OF NOOSPHERIC EDUCATION SYSTEM FORMATION
}

\author{
Nataliia Bakhmat \\ Kamianets-Podilskyi Ivan Ohiienko National University - Kamianets-Podilskyi (Ukraine) \\ Nataliia Ridei, Nataliia Tytova, Vladyslava Liubarets, Oksana Katsero \\ National Pedagogical Drahomanov University - Kyiv (Ukraine)
}

\begin{abstract}
Scientific (scientific and technical) multidisciplinary project activities for the formation of methodology of security and quality of life through the development of the noospheric education system require studying, developing, implementing and testing multivariate models and characteristics of modernized training system for specialists and professionals of a new kind, which are able to confront the global environmental challenges. Such training system provides the implementation of the system administration methodology of multuvariate noosphere-oriented training models (based on the principles of safety and quality of life), retraining, advanced training and training of kindergarden teacher school teacher - university teacher - mentor - scientist - person engaged in study process. The study takes into account the next principles and approaches: 1) noospheric, qualchoice, futuristic, constructive-problematic, situationalinnovative, energetic and goal-oriented, normative-axiological, culturological, system approach, information approach, synergetic, integrated, problem scenario approach, structural-functional, genetic and morphological, socio-cultural approach etc. as the scientific knowledge of the system state and development; 2) integrated methodology functions (critical and expert, criteria and indicative orientation (targeted), analytically relevant such as heuristic, instrumental, technological, predictive, philosophical, creative etc.) aimed at the prediction, remediation and prevention of environmental risks and civilizational development dangers. These functions include educational and research modules of noospherology, the system administration methodology, qualchoice (safety and quality of life), forecasting and modeling positive psycho-emotional development; 3) development of online workshop network to prepare job seekers (holders of educational and academic degrees) out of all stakeholder categories; 4) integration of the multivariate semantics of the higher education institutions and scientific institutions in the fields of ecology, environmental protection and balanced nature management, governance and public administration, pedagogy, contributing to the institutional modernization
\end{abstract}


of cross-border collaboration at the global, regional, national and institutional levels, as well as administrative management of the portability of scientificmethodical and information-analytical network of logistics, based on the system of noospheric education on the principles of autonomy, accessibility, continuity, academic mobility, ethics and integrity, health of the nation in the consortium of universities for the sake of security guarantees and the quality of life in biosocial dimension.

The modern methodological directions of safety and quality of life research are formulated in the global dimension. The current state of the problem is also characterized in the research. The target component of the actualized scientific problem is concretized due to contradictions, methods and means of research. The novelty and structure of the sphere of scientific research are determined. The author's interpretation presents the definition of "methodology of safety and quality of life on the basis of noosphere education", highlights the stages of research, proposes a hypothesis of scientific direction, its novelty and provides the conclusions to achieve the benefits of its relevance.

Keywords: noosphere development, safety and quality of life; human ecology; ecological and educational policy; global ecological challenges; socio-ecological comfort of environment

\section{Introduction}

The global scientific problem faced in the process of modern methodological research is fundamental, specific scientific methodology of expert assessment and systematic management of safety and quality of life in terms of civilizational and environmental challenges such as existence crisis and social adaptation crisis. The cornerstone of socio-cultural form occurs in the formation and transmission of modern scientific knowledge as portable educational and research programs to obtain the noosphere of competencies in the chain of the kindergarden teacher-school teacher-university teacher-mentor-academic employee. Modern professional profiles primarily include the elimination of the psychological, socio-economic and legal risks of psycho-pedagogical burnout through the determination to train specialists and professionals for all categories of applicants (applicants of all educational, educational-scientific and scientific degrees) in the context of global environmental problems, pandemics, the lack of security guarantees and the possibilities of academic mobility without the guarantee of a future employment renewal, family protection and health and responsibility of the internal and external administrative control in the sphere of education, science and innovations, including the responsibility of states and governments. Taking into account all the aspects mentioned above, not only Ukraine, as a state, but also as an ecosystem (natural social, urban, agro-, techno-) terrestrial and aquatic in nature (for types and functions) and the members of the EU and the United States, and all the continents require a new generation of specialists as translators of modern scientific knowledge and education. 
It requires cross-border integration for the new network forms of the noospheric education system to ensure the safety and quality of life for present and future generations. After all, biosocial systems of modern civilization development are now in a crisis state. And mankind was not prepared for it, starting from the basic sanitary and hygienic norms, health esbergen at home, work, in a closed space, remote communicative interaction and connection with the surrounding environment in terms of a distance. Noosphere training should provide not only modern futuristic scientific knowledge, but also the safety and quality of life of pupils, applicants, students, job seekers, families, groups, societies, in which the role of kindergarden teacher - school teacher - university teacher - mentor - scientist and all categories of noospheric education applicants are now actualized.

\section{Method}

The objectives of the research require using the next scientific methods:

- theoretical (systemic-axiological, structural-comparative, structural and logical, structural-functional for the implementation of the comparative analysis of global and domestic experience of the noospheric education system amplitude formation according to its semantic purposes; content analysis, quantitative and qualitative study of the textual and graphical information in formalized state and department documents for interpretation and forecasting; exalgo-acmeological analysis, theoretical systematization to characterize the main role of academic schools in shaping of futuristic science-methodical competence in the noospheric world; structural and logical analysis and classification with the aim to characterize the features of vocational training of kindergarden teachers - school teachers - university teachers - mentors - scientists of a new formation; classification, systematization, modeling, analysis and a chronological, retrospective, comparative, simultaneous synthesis to map the mainstream and special scientific views on the research problem, the definition of conceptual and categorial apparatus of the research and systematization of scientific knowledge for the disclosure of theoretical and methodological foundations and conceptualization strategy of the noosphere-oriented training of future kindergarden teachers - school teachers university teachers - mentors - scientists; pedagogical modeling; logic synthesis; axomatic formalization (highlighting the architectural forms of organization of educational-scientific process and study of the noospheric education system amplitude), hypothetical-deductive (general formulation on the basis of partial working and hypothesis); simulation noospheric education systems with the focus on security and quality of life in the context of global environmental risks and hazards;

- general scientific methods (generalization and systematization of modern scientific research and knowledge information for the content formation of the noosphere training for specialists and professionals, formal-logical method of legal 
documentation analysis, state description and civilization trend forecast and determination of the training level of future teachers and teachers according to the relevance of training and evaluation of employers and stakeholders);

- specific scientific methods of psychological and pedagogical research (formalization by axiomatization of research hypotheses; geographical method to determine the professional crosses by administrative-territorial division of the country, which allows to establish the necessities of higher education institutions (hereinafter HEI) and employment subjects of educators - kindergarden teachers - school teachers - mentors - research and teaching staff - students; disciplinary, interdisciplinary (choice of integrated ways to combine different component modeling levels of subsystems aimed at the involvement and completeness of the synergy of noosphere training systems for safety and quality of life)).

\section{Materials and procedure}

Tools of the study. The research tasks are to be solved through the applied complex of administrative, managerial, scientific-methodical, psychological-pedagogical influences in relation to the content of education, methods, forms, teaching techniques, interaction of educational-scientific process subjects, etc.

Methodically-organizational subsystem of the noosphere synergy training system combines forms, methods and means of education, research, evaluation training and knowledge-based applications, products, services, based on scientific and methodological foundations of training and professional development of competence synergy in the continuous training in educational, scientific, practical forms. It includes the complete set of applicants' education, administrative territorial location, the dual methods of educational and cognitive activities, motivational and stimulating analytical research, interactive and situational monitoring, self-evaluation, and corrective diagnostics by means of analytical, technical and scientific software. The research results will be represented as graphic presentations on various media, multimedia. Instruments, laboratories, scientific-methodical and technical-regulatory tools are scheduled to be activated according to the classification features due to the fundamental philosophical tools (phenomenological milestones of educational and scientific preparation process, interpretation and analysis hermeneutics of scientific and methodological support for social and humanitarian, sociopolitical modules in cycles of the noosphere training). The other scientific methods, used in the research, include scientific worldview (fundamental system theories of and system quality analysis of the components, state, and transformational change), specifical scientific methods (natural, social and human components of the educational-scientific process), disciplinary and interdisciplinary research methods (in the fields of science and knowledge and its synergistic integration). Scientific knowledge in the field of educational Sciences and Humanities demands applying the next methods: empirical (traditional, taxonomic, lexical-semantic, calibration), 
the methodology of knowledge (evidence, analysis and synthesis, pedagogical audit, monitoring, competence development modelling and forecasting, professional development, planning, formation of pedagogical hypotheses, theories, prevailing paradigms); statistic (generalization, classification, specification, analysis of multiple factors in sustainable chains of chance and probability).

\section{Result and Discussion}

\section{Analysis of recent research and publications.}

The education system development for sustainable development in Ukraine was studied by the next scientists: 1) teachers (Bogolyubov, 2013), (Pometun, 2015), (Kalinina, 2019); 2) ecologists (Bilyavsky, 2004), (Klimenko, 2013), (Stepanenko, 2007); 3) specialists in strategic management (Bekh, 2019), (Melnik, 2005, 2009, 2012); 4) foreign scientists (Moiseev, 1985, 2003), (Ursul, 2012), (Romanovich, 2006) etc.

Leading European environmental scientists from study the global environmental challenges on a global scale, for example, such scientists (Rik Leemans, 2019) and specialist in environmental policy (Arthur P.J., 2006, 2018) from the Netherlands, environmentalists and geneticists from the United Kingdom and China (Michael Snyder, 2016), ( Zhang, Zhang, Li \& Tian, 2018), as well as leading UNESCO experts (United Nations Educational, Scientific and Cultural Organization) ( Rene, Shu \& Jegatheesan, 2019).

\section{Selection of previously unselected parts.}

The purpose of the study is a theoretical and methodological substantiation of functional aspects of the noosphere education system to ensure safety and quality of life. The object of the study is the development process to create a methodology, ensuring safety and quality of life in the noosphere education system. The subject of the research is a multivariate amplitude of noosphere education systems of semantic purpose.

The tasks of the research are to substantiate the modern interpretation of the scientific problem in the conditions of global bifurcation of ecological dangers, to analyze the current state features of security and quality of life, to determine the functional purpose of the education system in a pandemic, to study the fundamental aspects of noosphere education, to substantiate the necessity to establish crossborder systems of noosphere development of life support for the future generations and the necessity for psychological and emotional support for the modernization of the educational sustainability paradigm for security and quality of life.

This scientific (scientific and technical) activity logically prolongs the succession of international projects (TEMPUS-SMHES "QANTUS", TEMPUS "ENAGRA", JET "IBMBASMA", EM Action 1, 2 Partnership "The Erasmus Mundus Action", USDA) and state projects ((GDR) theoretical and methodical bases of 
postgraduate education system formation on the basis of sustainable development» DR0117U004904), involving authors' participation and participation of the assosiated scientific academic institutions at a new qualitative stage of methodology research of safety and quality of life on the basis of noosphere education system formation in the conditions of global ecological and civilizational challenges.

\section{Presentation of the basic material}

The relevance of the chosen scientific problem of multidisciplinary research is the necessity to form the civilizational ability for noospheric development and possibilities to respond to global environmental challenges such as global civilizational problems regarding environment problems, terrorist, bio-diversionary nature of neglect and political bias disregarding the safety and quality of life of all its representatives in violation of the ecological balance of the noosphere sustainability. Socio-ecological modernity requires modernisation of education systems and provision of noosphere strategy to prepare specialists and professionals in the chain of kindergarden teachers - school teachers - university teachers - science teachers - applicants of education competencies of current scientific knowledge in the field of ecology, information and socio-environmental quality management, security of life, human ecology, religious studies, environmental and educational policy, psychology, positive psycho-emotional intelligence. This year civilization changes within a few months paralyzed the strategy of regime security services, internal connections, health, education and science systems, social and information support. But these changes also led to a new stage of noospheric awareness acquisition about ecological valence and human life values, nature preservation and reproduction, the integrity of the family. It helped to adopt and develop the common understanding of methodological solutions for network and the urgent necessity to establish a new noospheric education system. Crisis monitoring assessment of the current state and future development of modern education, science and innovations proves an urgant demand to transform the HEI administrative and managerial staff. Such transformations require engaging to the educational-scientific process physicians, lawyers, sociologists, psychologists, ecologists, philosophers, religious scholars in peacekeeping cooperation and accountability in the government, representatives of the security service, non-governmental organizations, regional, state and continental associations for the training of specialists and professionals, capable of transmitting the modern scientific futuristic knowledge of safety and quality of life of the noosphere civilization development to ensure the future of coming generations.

The research topic is actualized and determined due to the next contradictions: 1) contradictions in organization of cross-border cooperation to ensure security and quality of life and legal regulation of cross-border cooperation. There are some problems regarding the lack of contact and synchronization of legal decisions 
made at the state, national and regional levels in the field of linear implementation through modern education, science and innovation; 2) contradictions between the current education systems and science and the lack of integrated international standardization principles of safety and quality of life based on the noosphere approach; 3) contradictions between the current inhibitory administrative and managerial apparatus of the HEI organization, especially, pedagogical apparatus, which is entrusted with the majestic mission to ensure the quality of life of future generations and socio-ecological demands.

The scientific novelty of strategic multidisciplinary research is the next one. For the first time, the multivariate models, the network organization amplitude of the noospheric education system with evidence of the safety and quality of life are developed, justified and implemented in the West in the fields of "Ecology, environmental protection and balanced nature management", "Governance and public administration" and "Pedagogy".

It is planned to improve methodological approaches and the of expert assessment methodology of functioning, the methodology of noospheric education system management with evidence of the safety and quality of life. It is also planned to develop academic service methods, the noospheric education system formation in the context of global environmental problems, to create a scientific-methodical informational database of the leading institutional participants in the project concerning assessment methodology of the development state and noospheric education system consequences with evidence of safety and quality of life to ensure the biosocial stability, to establish the International Academic Service Center with national and the EU HEI partners.

It is expected to prepare the methodical recommendations on the HEI structure modernization according to the modern requirements of the network form of the noospheric education system, to create the original courses such as "Noospherology", "Methodology of system management", "Qualitology", "Forecasting and modeling positive psycho-emotional development" by the leading project participants, to develop a network of online workshops.

The structure of the study regarding the methodological justification of approaches to security and quality of life through the effective functioning of the noospheric education system includes the following components: 1) multivariate amplitude models of the noospheric education system network organization with evidence of safety and quality of life; 2) methodological approaches to the noospheric education system functioning with evidence of safety and quality of life; 3) administrative, psychological and pedagogical, organizational legal activities of the International Academic Service Center and methodological support, development, implementation of noospheric education network system on the principles of safety and quality of life; 4) substantive and methodological modernization content of the academic methodological support service, including the development and 
imlementation of noospheric education network system on the principles of safety and quality of life, and the establishment of legal and technological regulation standards and the capacities of the existing material technical basein order to provide monitoring of the educational and research process quality; 5) modernization of the HEI structures according to the modern requirements of the network form of noospheric education system; 6) implementation of the voluntary compliance of assigned duties an academic virtue and culture regarding the functioning of the noospheric education system with evidence of the safety and quality of life through the integration of the Association of Universities for sustainable development.

The research methodology provides justification, development, planning and implementation of theoretical and methodological aspects of the noospheric education system to ensure the safety and quality of life. It is based on causal link and space-time interaction between the program and the results of theoretical and experimental studies, which include scientific-methodical, logistical, communication, software, scientific-metric complex support for the development of information and reliable basis for the further creation of plans, programs, projects, forecasts, models, scenarios, and practical use of the study results. Research methodology is used as a system of modern scientific knowledge about the methods, techniques, standards of evaluation (and their security) in newly diagnosed qualitative changes in its substantive content.

Methodology of safety and quality of life, based on the principles of the noospheric education system functioning, is seen by the authors of the project as multidisciplinary (according to branches of sciences and knowledge) and multimodule (on the platforms of the types and levels of environmental social organizations and political engagement in the ecosystem, noosferologic principles of supply permanence for future generations) study of the methodology of system safety management. (Methodology of safety and quality of life is studied in: 1) types: personality, society, state; 2) kinds: political, economic, social, military, ecological, scientific-technological, information kind; 3) levels: according to situation diagnosis (interpretators-situational assessment), according to spread area (spatial-geographical, administrative-territorial, ecosystem-area link, subsidiary territorial-civil), according to functions (sectoral semantic eco-system-functional, geologic-emotionally-intelligent, assertive-stable, adaptive, synergistic matrix management-institutional hierarchy of the noospheric education system functioning (forms, types, levels of organization and semantics of educational, educational-scientific and research institutions, through the geopolitical, governmental and institutional mechanisms of public management)). The study of the methodology of safety and quality of life is to ensure the elimination of life risks and hazards, the maintenance of social mobility guarantees and prolonged employment for life, equal availability and efficiency of the exalgo-acmeological implementation of the competence qualification in the conditions of global environmental challenges in civilization development and quality of life. (Quality of life is considered as the degree 
of satisfaction of spiritual, cultural, theological and material, socio-environmental necessities and protection of life on the Planet, Human life and his descendants' life in biospheric-noospheric dimension of consistency. Quality of life is assessed at a ratio of requests (desire to get happiness) to the necessities of human development to the base of standardized measurements of viability in the context of global environmental challenges of bifurcations on a planetary scale (ecological footprint of Nations), highlighted in the subjective self-assessment of their own qualchoice potential of self-actualization (abilities, quality, readiness, formation, competence) and external monitoring of Individual's acmeological potential perception ability in the biosphere-social interaction. Objective-subjective criterion metric of quality of life involves the physiological health and safe-security settings (the sum of evaluation indicators of physical comfort and discomfort of life in the system environment, spirituality and personal beliefs), psychological-emotional-compensatory intelligence (psycho-compensatory stability of self-perception, self-esteem, self-concentration, noospheric thinking, both private and paradox empathy in harmony with ecological culture, psychological health, desire to live and improve oneself) and social welfare (synergistic social interaction systems of education, science and innovations in the context of a pandemic, the inclusion of bifurcations of civilizational development, inequality, social insecurity, with no guarantee of prolonged employment and survival for the desired parameters of quality, home environment, comfort of the environment, health and safety, human ecology, leisure satisfaction, and possibility of public access to environmental information in global, transcontinental, regional and local scales related to anthropogenic pressures and socio-environmental situations), the complex of which is public socio-ecological health of the noosphere civilization development).

The main stages of this study include: evidence-based systematic procedures of evaluation; targeted research results and learning processes (their focus, intensity, and the quality of the transformation states); standardization of the estimation algorithm of strategic plans and programs compared with current methodological standards, which are due to the task to achieve the goal of strategic planning to the implementation of plans and programmes with subsequent conversion goals; improvement of strategic plans and programs, consistent expectations and feedback from stakeholders to improve their implementation on the principles of transparency, openness, responsibility and accountability.

The hypothesis of the study is the next one. Society can be formed at the next stage of mankind civilization development while being in the crisis bifurcation of environmental challenges, risks and dangers of degradation and destruction of the biosphere, noosphere among students (schoolchildren, applicants for educational services and different categories of public organizations) with the provision of noosphere consciousness, thinking, environmental culture for the formation of appropriate level and quality of life through the effective functioning of noosphere education, science and innovation transcontinental network level 
of the organization on the basis of sustainability through research, development, provision and implementation of fundamental and applied principles of safety management and quality of life through modernization of implemented regulatory standards and social guarantees of any individual's multivariate portable training, mobility security, prolonged employment etc. to modern living conditions with competencies of safety, qualitology, noospherology, human ecology, quality management, education, research, educational, environmental, social, national and transnational safety and quality of life policy.

\section{Discussion}

In the course of scientific (scientific and technical) work it is planned to provide a systematic multidisciplinary research in the field of methodology of security and quality of life through the development of the noospheric education system and scientific and technical development with the aim of obtaining scientific, technical (applied) and scientific (scientific and technical) products and modern models of noospheric education in different ways for the training of specialists and professionals in the environmental profile and preadolescence, educational-scientific, management and administrative network activities.

The next results are provided: 1) development of regulations, conduct a public discussion among the academic community HEI-partners and the creation of the International Academic Service Center in National Pedagogical Dragomanov University for the formation of a substantial methodological content and the collective and individual expert assessment methods of the modern noospheric education system state and development and a priority of multidisciplinary scientific research in the field of security and quality of life; 2) formation of scientific and methodological information database based on the platform of "Educational space futuristic scientific knowledge" in the fields of different sciences such as ecology, environmental protection and balanced environmental management, governance and public administration, pedagogy.

It is planned to prepare the monographs "Polaron model of the noospheric education system on the principles of safety and quality of life", "Noospheric approach in the context of global environmental risk". It is also planned to implement and test the experimental lecturers in networked systems of education, science and innovation, to provide permanent conditions of life for future generations.

The advantages of scientific-technical products are that courses exist only as foreign tangent analogues of an applied nature. The involvement of the leading Ukrainian scientists from different branches of science and knowledge will contribute to the fundamental training courses and advanced level subjects.

The platform "Educational space futuristic scientific knowledge" will provide an inventory of current scientific data and it will help to enhance the development of new methodological approaches to activate the public access to contemporary ecologi- 
cal knowledge according to the requirements of the Aarhus Convention. Methods of expert assessment of strategic plans and programs of the modern civilization development do not exist in Ukraine. Therefore, the semantic orientation of modernized systems of education, science and innovation requires cross-border transformation, acquisition of network forms of organization, contemporary models of noospheric education system diversity with evidence of the safety and quality of life.

Justification of the advantages of the expected scientific or scientific and technical products (if any) in comparison with existing analogues : author's courses exist only in foreign tangential analogues of an applied nature. Involvement of leading Ukrainian scientists in various fields of science and knowledge in the project will contribute to the fundamental preparation of courses in progressive disciplines. The platform "Educational space of futuristic scientific knowledge" is an inventory of modern scientific data. It will not only enhance the development of new methodological areas, but also provide public access to modern environmental knowledge in accordance with the requirements of the Aarhus Convention. There are no methods of expert evaluation of strategic plans and programs of modern civilization development in Ukraine. The semantic orientation of modernized education, science and innovation systems requires cross-border transformation, the acquisition of a network organization form of modern multivariate noosphere education system models with signs of safety and quality of life.

\section{Conclusion}

Theoretical and methodological substantiation of the conceptual and categorical apparatus of safety and quality of life methodology on the basis of network formation of the noosphere education system, analysis of normative-legal and technical regulation of traditional systems of continuous education.

Develop the Center of International Academic Service, coordination of crossborder interaction of polyvariant models of educational and scientific systems; methodical recommendations for the analysis of tangential projects of methods of polyvariant interaction of models of systems of noosphere training of specialists of new formation ; technical and economic analysis of the information and telecommunication network of the noosphere network system with inventoried data of the expert evaluation methodology to ensure the sustainability of future generations; substantiation, development of multivariate models and design of methodological support for their effective implementation.

Performance indicators (what scientific or other result will be obtained at a certain stage) : methods of scientific knowledge of quality and safety with expert evaluation of the noosphere education system; preparation for publication of collective monographs "polyvariant models of noosphere education systems on the basis of safety and quality of life", "noosphere approach in the context of global environmental risks"; introduction and approbation of experimental author's courses 
in network systems of education, science and innovation to ensure sustainable living conditions for future generations.

Polyvariant models of noosphere education for safety and quality of life with prolonged employment of human potential.

Formation of an inter-institutional consortium of noosphere education system cross-border modernization on the basis of safety and quality of life; acquire futuristic success of potential features and cross-border integration of education, science and innovation systems of global, regional and national levels for modernization on synchronized basis of the noosphere education system under the conditions of legal implementation and technical regulation of safety, quality of life; to determine the classification features of the national semantics of education systems, science and innovation of the free economic zone of ukraine in order to substantiate, develop and implement unified methodological principles of quality and life safety for the formation of the system of noosphere education; methodologically substantiate the statutory institutional interaction of the network form of organization of the noosphere education system to develop the formation and improvement of quality and life safety methodology for all categories of students and providers of educational and scientific services in order to ensure prolonged lifelong interaction based on the noosphere approach; development of models and coordination of scientific and educational programs, inventory of information and communication portable platforms of education, science and innovation during life; polyvariant models of the noosphere education system for safety and quality of life with guarantee of social dimension; introduction and synchronization of transcodon and polyvariant interaction of models of noosphere education and their approbation for the sake of safety and quality of life of future generations through scientific knowledge of the teacher and his followers; assembly of scientific results of leading scientists in the fields of science ecology, environmental protection and sustainable use of nature, public administration and public administration, pedagogy.

Performance indicators (what scientific or other result will be obtained at a certain stage) : development and theoretical and methodological substantiation of the system methodology for managing the study of safety and quality of life in the system of noosphere education; regulatory regulation of cross-border interaction of noosphere orientation systems with measurement of safety and quality of life for prolonged realization of human potential; implementation and implementation of systems of noosphere training of teachers and students in the process of scientific knowledge.

Future work will. Description of ways and means of further use of project implementation results in public practice: Methodology of safety and quality of life on the basis of the noospheric education system formation, in practice, provides academic mobility, cross-border cooperation and social and legal guarantees within the cooperation framework of the European Union and transcontinental re- 


\begin{tabular}{|c|c|c|c|c|c|}
\hline 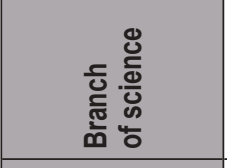 & 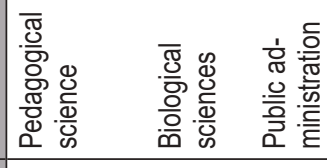 & 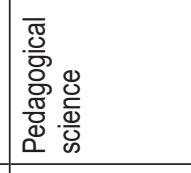 & 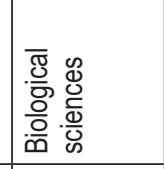 & 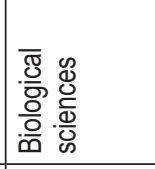 & 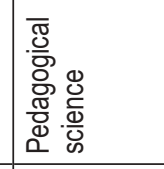 \\
\hline 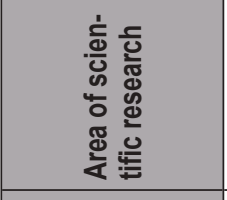 & 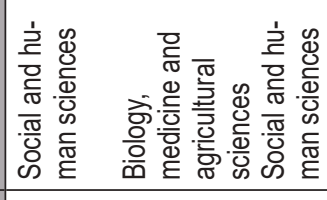 & 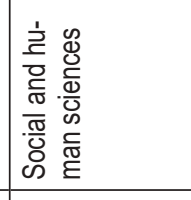 & 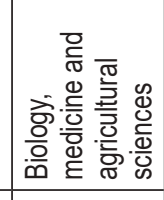 & 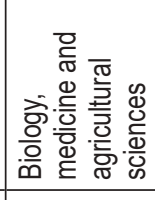 & 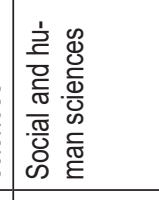 \\
\hline 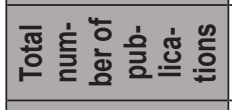 & $\begin{array}{l}8 \\
8 \\
8\end{array}$ & 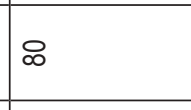 & $\overline{\text { N }}$ & 芩 & 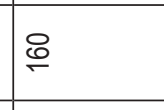 \\
\hline 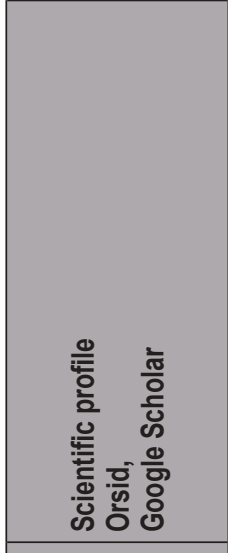 & 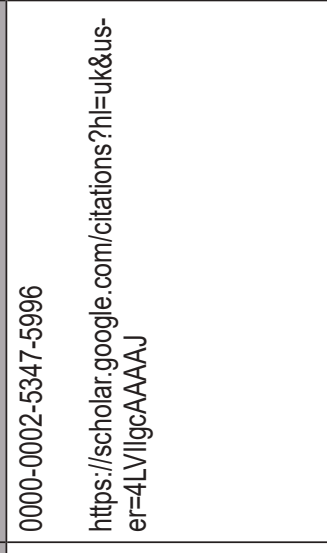 & 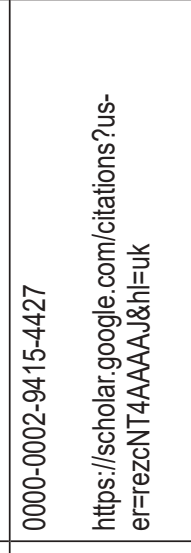 & 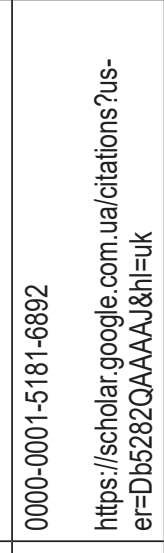 & 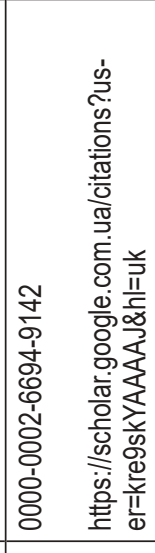 & 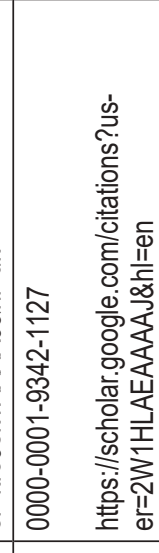 \\
\hline 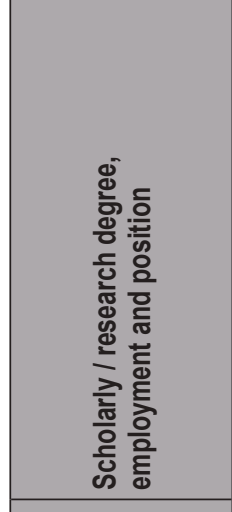 & 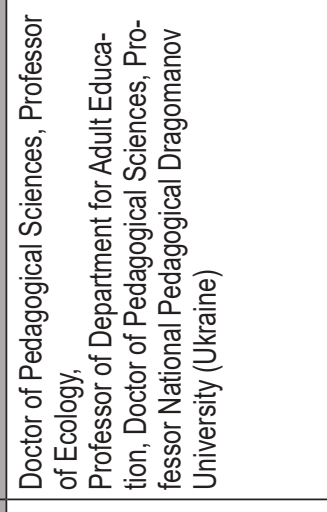 & 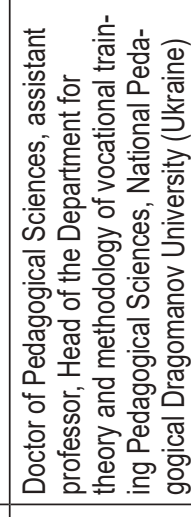 & 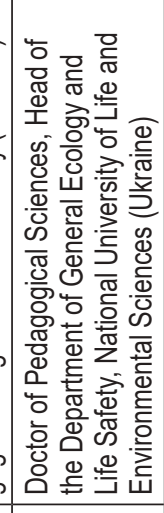 & 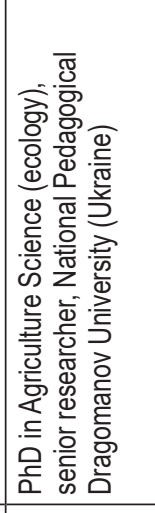 & 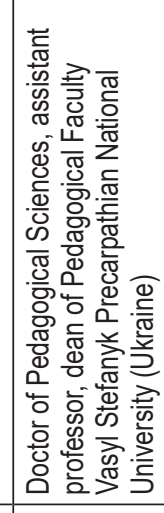 \\
\hline 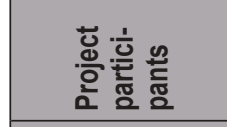 & 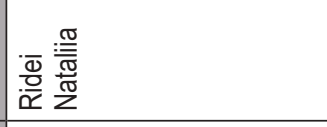 & 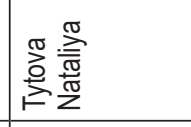 & 言 & 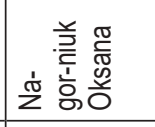 & 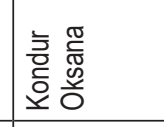 \\
\hline$\frac{a}{D}$ & |- & ¿ & ळ. & 过 & 皇 \\
\hline
\end{tabular}




\begin{tabular}{|c|c|c|c|c|c|}
\hline 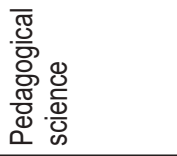 & 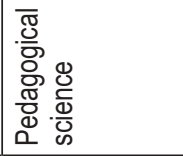 & 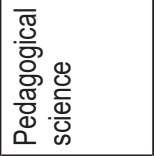 & 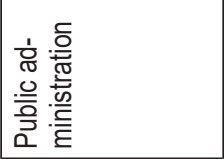 & 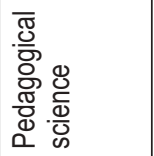 & 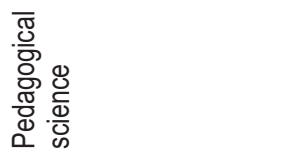 \\
\hline 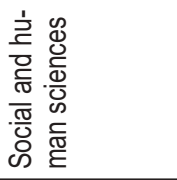 & 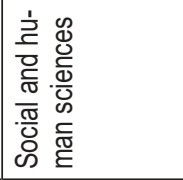 & 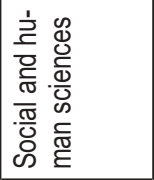 & 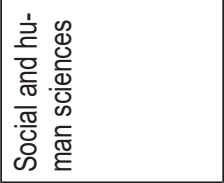 & 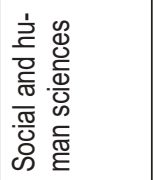 & 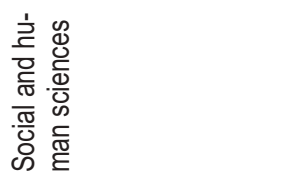 \\
\hline$\hat{\sim}$ & 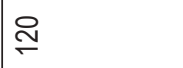 & م & $\stackrel{\infty}{\infty}$ & 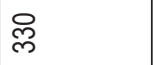 & $\stackrel{\infty}{\circ}$ \\
\hline 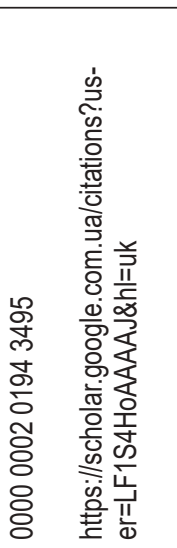 & 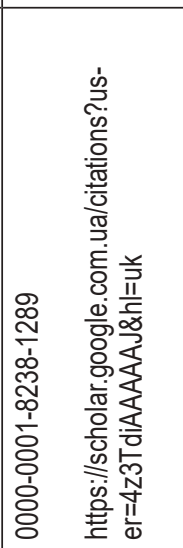 & 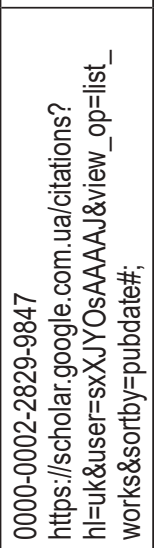 & 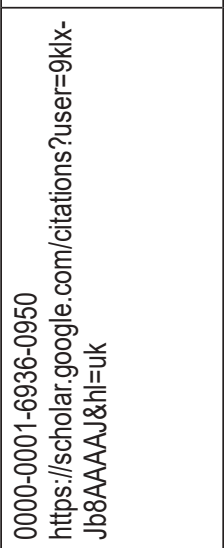 & 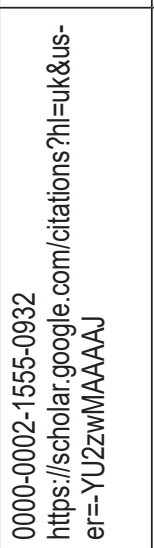 & 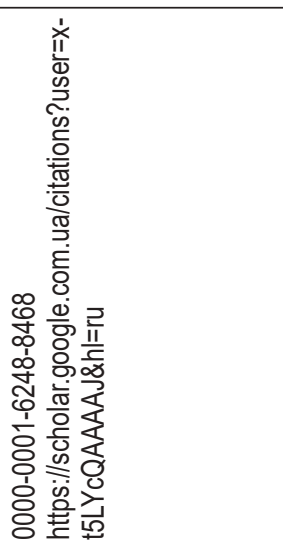 \\
\hline 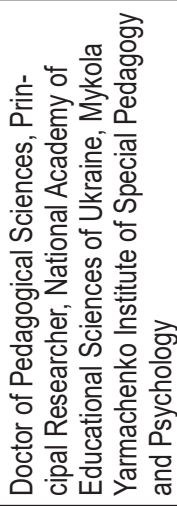 & 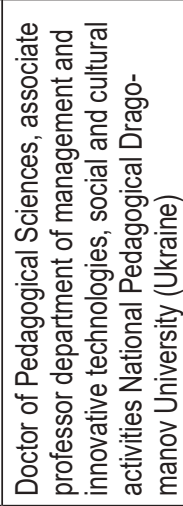 & 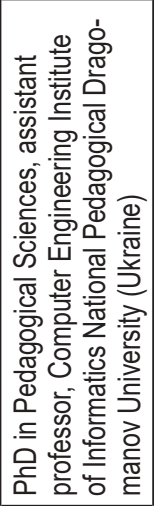 & 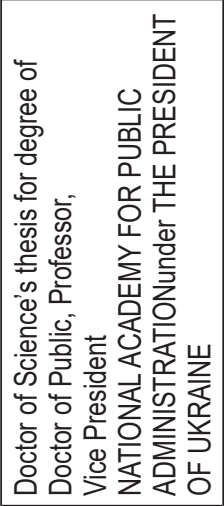 & 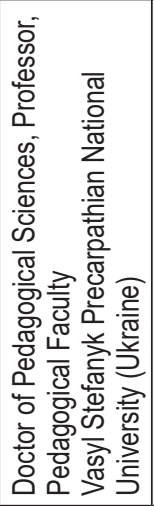 & 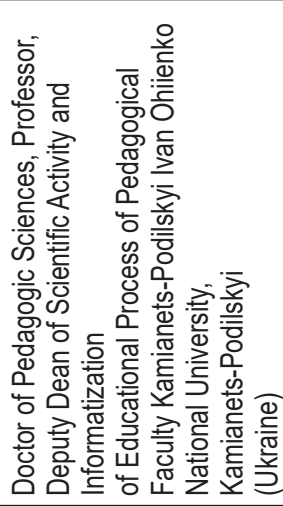 \\
\hline 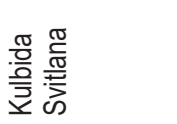 & 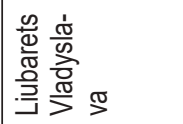 & 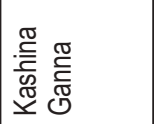 & 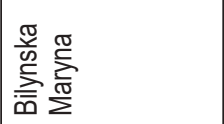 & 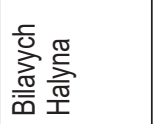 & 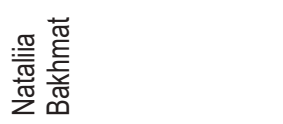 \\
\hline$\varnothing$ & $\hat{N}$ & $\infty$ & வ் & $\mp$ & $\stackrel{F}{F}$ \\
\hline
\end{tabular}


lations, the European credit system, Asia-Pacific, American credit accumulation systems for the formation of a network system of noospheric education for future generations. The system of noospheric education is formed in constant interaction between consortiums of different universities in terms of Talaur agreement involving the institutions for sustainable development. International terrorism, pandemic and other disasters cause the lack of quality of life and safety. So far it requires rebuilding modern streamlined system of noospheric education, which is able to provide guarantees for the protection of the social dimension and legal protection. Every member of society should be guaranteed to have access to scientific knowledge and education throughout life by means of portable programs (educational, scientific, informational, journalistic) and emulation between the great mission of the teacher-researcher and his students, who are the keepers of the methodologically interdisciplinary professional competence of security and quality of life.

Possible risks of unrealistic interaction in the conditions of incorrect administrative interaction (lack of administrative cooperation, incorrect testing of the antiplagiarism system, non-identifiable means, quartiles, etc; . vulnerability of children within the education system reform, because they are forced to flee and study abroad; lack of free choice in scientific research due to financial constraints in the hei, departmental board and unnecessary national agencies).

\section{REFERENCES}

Mol, A. P.j. (2006). Sociological Perspectives for Industrial Transformation. Doi: 10.1007/1-4020-4418-6_3.

Mol, A. P.j. (2018). The Environmental State and Environmental Governance. Environment and Society, 119 - 142. Doi: 10.1007/978-3-31976415-3 6.

Bekh V. P. (ed.) (2019). Identity in the maelstrom of the planetary world.

Bekh Yu.V. (ed. by V. P. Bekh) (2015). Philosophical Mode of the General Management Theory. Kyiv : Dragomanov NPU Publishing House.

Belyavsky, G. A. and others (2004). The concept of environmental education.

Bogolyubov, V. M. (2013). Sustainable development of society: socialecological aspects of formation of professional competence of masters in ecology.

Bogolyubov, V. M., Klimenko, A. G., Miller, L. G. etc. (2012). Strategy for sustainable development.

Fronzek, S., Carter, T.R., Pirttioja, N. et al. (2019). Determining sectoral and regional sensitivity to climate and socio-economic change in Europe using impact response surfaces. Reg Environ Change 19, 679-693 https://doi.org/10.1007/s10113-018-1421-8 
Rene, E. \& Shu, L. \& Jegatheesan, V. (2018). Environmentally friendly (Bio) technologies for the removal of emerging organic and inorganic pollutants from water. Journal of Water Supply: Research and Technology-Aqua. 67. 10.2166/aqua.2018.000.

Kalinina L. M. \& Malyuga N. M. (2019). The Ukrainian experience of crowdfunding in the social sector. The dynamics of the development of modern science: materials of international scientific conference (15 November 2019) the international center for scientific research.

Robinson, K. \& Aronica, L. (2016). School of the future. Revolution in your school that will forever change the education.

Klimenko M. A., Gerasimchuk Z.V., Klimenko A. M. etc. (2015). Razuitoare.

Shmandiy, V. M., Klimenko M. A., Golik Y.S. \& Prischepa A. M. et al. (2013). Environmental Security: textbook.

Levkovskiy, K., Stepanenko S. \& Timoshenko N. (2007) Education for sustainable development.

Melnik, L.G. (ed.). (2009). Sustainable development: theory, methodology, practice.

Snyder, M. (2016). Genomics and Personalized Medicine: What Everyone Needs to Know. New York: Oxford University Press.

Miller, L. G. (2005). Methodology development.

Moiseev, N. N., Aleksandrov V. V. \& Tarko A. M. (1985). Man and the biosphere: the Experience of systems. analysis and experiments with models.

Pometun, E. I. (2015). Pedagogical bases of education for sustainable development in Ukrainian schools.

Romanovich, A. L. \& Ursul, A. D. (2006). Sustainable future (globalization, security, noospherogenesis).

Ridei, N. M. (ed.) (2019). Management of postgraduate education systems for sustainable development.

Ridei, N. M. \& Sergienko, V. P. (ed.) (2017). Multimodus the basics of postgraduate education for sustainable development.

Nunez, S., Arets, E., Alkemade, R. et al. (2019). Assessing the impacts of climate change on biodiversity: is below $2{ }^{\circ} \mathrm{C}$ enough?. Climatic Change 154, 351 - 365 https://doi.org/10.1007/s10584-019-02420-x

Tytova, N. M. (2018). Theoretical and methodological foundations of psychological and pedagogical training of future teachers 'professional training.

Ursul, A.D. \& Ursul, T.A. (2012) Global research and the formation of the noosphere through sustainable development Doi: 10.7256/24540684.2012.4.6511. 
Zhang, W., Zhang, L., Li, Y. \& Tian, Y. (2018). Neglected environmental health impacts of China's supply-side structural reform. Environment International, Doi: 10.1016/j.envint.2018.03.006

$\triangle$ Prof. Nataliia Ridei

ORCID iD: 0000-0002-5553-059X

Department for Adult Education, National Pedagogical Drahomanov University

Kyiv, Ukraine

E-mail: nataliia.ridei@gmail.com

$\triangle$ Prof. Nataliia Bakhmat

ORCID iD: 0000-0001-6248-8468

Department of Theory and Methods of Primary Education Kamianets-Podilskyi Ivan Ohiienko National University

Kamianets-Podilskyi, Ukraine E-mail: bahger.teacher@gmail.com

$\triangle$ Dr. Nataliia Tytova, Assist. Prof.

ORCID iD: 0000-0002-9415-4427

Department of Theory and Methodology of Vocational Training

National Pedagogical Dragomanov University

Kyiv, Ukraine

E-mail: titnat2008@ukr.net

$\triangle$ Prof. Vladyslava Liubarets

ORCID iD: 0000-0001-8238-1289

Department of Management and Innovative Technologies, Social and Cultural Activities

National Pedagogical Dragomanov University

Kyiv, Ukraine

E-mail: v.v.lubarets@ukr.net

Ms. Oksana Katsero, PhD student

ORCID iD: 0000-0002-5347-5996

Adult Education Department

National Pedagogical Dragomanov University

Kyiv, Ukraine

E-mail: o.katsero@gmail.com 